\title{
Osmium isotope systematics of the Proterozoic and Phanerozoic ophiolitic chromitites: in-situ ion probe analysis of primary Os-rich PGM
}

\author{
Ahmed H. Ahmed ${ }^{1, *}$, Karen Hanghøj ${ }^{2}$, Peter B. Kelemen ${ }^{2}$, Stanley R. Hart ${ }^{2}$, Shoji Arai ${ }^{3}$
}

1. Central Metallurgical Research \& Development Institute, P.O. Box 87 Helwan, Cairo, Egypt

2. Woods Hole Oceanographic Institution, Woods Hole, Massachusetts, USA

3. Department of Earth Sciences, Kanazawa University, Kakuma 920-1192, Kanazawa, Japan

\section{Abstract}

In-situ ${ }^{187} \mathrm{Os} /{ }^{188} \mathrm{Os}$ ratios are determined on Os-rich platinum-group minerals in podiform chromitites both in the Proterozoic ophiolite, Eastern Desert, Egypt, and in the Phanerozoic Oman ophiolite. Because they have very low Re/Os, these primary minerals reflect the initial ${ }^{187} \mathrm{Os} /{ }^{188} \mathrm{Os}$ ratios of their parental magmas. The platinum-group minerals (PGM) in the central Eastern Desert chromitites exhibit sub-chondritic to chondritic ${ }^{187} \mathrm{Os} /{ }^{188} \mathrm{Os}$ ratios, 0.1226 on average, which is lower than the primitive upper mantle evolution trend of a comparable age. Those of the southern Eastern Desert chromitites have more radiogenic Os, with supra-chondritic ${ }^{187} \mathrm{Os} /{ }^{188} \mathrm{Os}$ ratio of about 0.1293 on average, which could be due to crustal contamination. The three chromitite types in the northern part of the Oman ophiolite are almost indistinguishable in terms of their ${ }^{187} \mathrm{Os} /{ }^{188} \mathrm{Os}$ ratios; they have overlapping values ranging from sub-chondritic to supra-chondritic ratios. The PGE-rich, mantle chromitite samples have a wide range of ${ }^{187} \mathrm{Os} /{ }^{188} \mathrm{Os}$ ratio from 0.1230 up to 0.1376 , with an average of 0.1299 . The values of the PGE-poor mantle chromitites overlap in their

\footnotetext{
* Corresponding author:

Fax +202 5010 639, E-mail address: ahmh2@yahoo.com
} 
${ }^{187} \mathrm{Os} /{ }^{188} \mathrm{Os}$ ratios with PGE-rich chromites, but are less variable and have a significantly higher average ratio. The Moho transition zone (MTZ) chromitites are highly variable in the ${ }^{187} \mathrm{Os} /{ }^{188}$ Os ratio, ranging from 0.1208 up to 0.1459 .

The wide range of ${ }^{187} \mathrm{Os} /{ }^{188} \mathrm{Os}$ ratios, from 0.1192 to 0.1459 , in platinum-group minerals in Egyptian and Oman ophiolites can be attributed to the diversity of origin of their podiform chromitites. The Os-isotope data combined with spinel chemistry indicate that the way involved in podiform chromitite formation was not substantially different between the Proterozoic ophiolite of Egypt and the Phanerozoic ophiolite in northern Oman. The Osisotope compositions of the mantle chromitites in the Proterozoic ophiolite of Egypt clearly suggest crustal contamination. The heterogeneity of ${ }^{187} \mathrm{Os} /{ }^{188} \mathrm{Os}$ ratios combined with the spinel chemistry and high PGE contents of the PGE-rich chromitite in the Oman ophiolite may give reliable evidence for high degree partial melting at a supra-subduction zone setting. Crustal contamination from the subducted slab, and assimilation of previously altered, lower crustal gabbro, may have contributed to the high $\mathrm{Cr} \#$ spinel and radiogenic Os characteristics in chromitite formed in the mantle section and along the Moho transition zone, respectively.

KEY WORDS: Chromitite; Egypt; Oman; ophiolites; Os-isotope; in-situ PGM analyses

\section{Introduction}

The rhenium-osmium pair forms an important long-lived isotopic system via the decay of radiogenic ${ }^{187} \operatorname{Re}$ to ${ }^{187}$ Os. During mantle melting, Os is generally highly compatible, whereas $\mathrm{Re}$ is moderately incompatible [1]. Consequently, crustal materials are extremely depleted in Os and somewhat enriched in Re compared to primitive and residual mantle rocks. The Re-Os isotopic system has been directly applied to the study of platinum-group elements 
(PGE) mineralization and related ore deposits. The ultimate source of Os can be definitely inferred from the large differences between the Os isotopic compositions of the crust and the mantle [2-4]. Osmium isotopic systematics, therefore, in combination with other geochemical characteristics, can provide unique information about the geological settings at which this PGE mineralization has been formed, as well as about the crustal recycling process in subduction zones [5].

Although discrete PGM inclusions within spinel in chromitite can provide constraints on the initial Os isotopic composition of the melt from which they formed, Os isotope data on such minerals in ophiolites are very limited [6-9]. This paper presents ${ }^{187} \mathrm{Os} /{ }^{188} \mathrm{Os}$ ratios of insitu Os-rich PGM included within chromian spinel from two ophiolitic chromitites: the Proterozoic ophiolite of the Eastern Desert, Egypt, and the Phanerozoic ophiolite of northern Oman (Fig. 1A and B) in order to constrain the Os isotopic composition of the depleted mantle. Osmium-isotope ratios of these primary PGM, generally included within fresh spinel grains, are expected to be least affected by post-magmatic processes and to have low Re/Os ratios, and therefore will closely approximate the ratios of the parent magmas involved in the chromitite formation. Although chromian spinel is one of the resistant mantle minerals against post-magmatic processes; i.e. serpentinization, and can potentially provide precise initial ${ }^{187} \mathrm{Os} /{ }^{188}$ Os ratios [10], the Os-rich PGM encapsulated within fresh chromian spinel are likely the best materials to constrain the initial ${ }^{187} \mathrm{Os} /{ }^{188}$ Os values. Here we also analyzed the ${ }^{187} \mathrm{Os} /{ }^{188}$ Os ratio and Os content for some bulk chromitite samples and compare these results with those of discrete PGM in chromite.

\section{General geology and sample descriptions}


It is now generally accepted that there are many dismembered ophiolites of different ages in the Red Sea Hills of the Eastern Desert, Egypt, and Saudi Arabia. Most of those exposed to the east of the Nile Valley are estimated to be late Proterozoic in age [11]. All the chromitites studied here in the Eastern Desert of Egypt are exposed to the east of the Nile, concentrated mainly in the northern and southern part of the Eastern Desert (Fig. 1A). Recently, several ophiolitic complexes have been recognized in the late Precambrian rocks (younger than $1100 \mathrm{Ma}$ ) in NE Africa and Saudi Arabia. The occurrence of ophiolite complexes and their association with calc-alkaline volcanic rocks of island arc affinities have led to the conclusion that subduction processes were responsible for the Pan African mobile belts of NE Africa and Saudi Arabia [11-15].

Numerous platinum-group minerals (PGM) have been recently described as discrete inclusions within chromian spinel of podiform chromitites both in the Oman ophiolite [16,17] and the Proterozoic ophiolite, Eastern Desert, Egypt $[18,19,20]$. The two ophiolite suites have different ages; Cretaceous age ( 96 Ma [21]) for the Oman ophiolite and late Precambrian age ( 784 Ma [11]) for the Egyptian ophiolite. The most common PGM in both ophiolites are Osrich laurite and, to a lesser extent, erlichmanite and Os-Ir alloys. The mineralogical compositions and morphological features of these PGM in Oman and Egypt are presented in details elsewhere [17,22]. In Egypt, ultramafic rocks are estimated to occupy about $5.3 \%$ of Precambrian outcrops in the Eastern Desert [23]. Mafic-ultramafic fragments of highly dismembered ophiolites are abundant in the late Precambrian Pan African belt of the Eastern Desert of Egypt and NE Sudan (Fig. 1A). Chromitite is concentrated in the central and southern parts of the Eastern Desert of Egypt as small and irregular pods hosted by serpentinized peridotites [24]. There are two distinct types of chromitite in the Eastern Desert of Egypt in terms of the location and spinel chemistry: the central Eastern Desert (CED) chromitites, and the southern Eastern Desert (SED) chromitites. The CED chromitites have a 
wide compositional range from high-Al to high-Cr spinels, whilst the chromitites of the SED consist of a very refractory high-Cr spinel, $\mathrm{Cr} \#>0.8$ (Fig. 2). Although almost all chromitites have been found to include some PGM, two chromitite pods at Wadi El-Lawi (LW) in the CED (Fig. 1A) are the most enriched in PGE and PGM known so far. Among various types of PGM inclusions in chromian spinel [22], Os-rich PGM (mainly laurite) and, to a lesser extent Os-Ir alloy, were used in the present study for in-situ Os-isotope analysis of the Eastern Desert chromitites of Egypt. The SED chromitites of Egypt usually contain Os-Ir alloy PGM, whilst the CED ones occasionally have PGM-sulfides, mainly laurite, as inclusions in spinel $[18,19,22]$.

The Oman ophiolite is a slice of lithosphere formed at an oceanic spreading ridge that was obducted onto the Arabian continental margin during the early Cretaceous [25]. Podiform chromitite in the northern Oman ophiolite occurs either within the MTZ or deeper within the residual mantle section [26,27]. The MTZ chromitite is found as irregular pods of different shapes and sizes at the uppermost part of the mantle section, just at the mantle-crust boundary. Three localities of MTZ chromitite have been investigated for PGM; Wadi Farfar, Wadi Fizh and Wadi Rajmi (Fig. 1B). Only few samples from Wadi Rajmi chromitite, named 29, 30, 32 and 60 (see Table 2), have been found to include some small PGM grains. The MTZ chromitite usually has a relatively low $\mathrm{Cr}$ content $(\mathrm{Cr} \# \sim 0.5)$ (Fig. 3) and low PGE concentrations, less than $200 \mathrm{ppb}$. The PPGE/IPGE ratio, i.e. $\mathrm{Pd} / \mathrm{Ir}$ ratio, is commonly $>0.1$ up to 0.75 [27] in the MTZ chromitites of the Oman ophiolite. Chromitites deeper within the mantle in this study are investigated from Wadi Hilti. In terms of mode of occurrence and spinel chemistry, mantle chromitites can be subdivided into two types: (1) discordant (dykelike) PGE-rich, with high-Cr spinel $(\mathrm{Cr} \#>0.75)$ and (2) concordant (lensoid shape) PGEpoor, usually with intermediate-Cr spinel, $\mathrm{Cr} \# \leq 0.6$ (Fig. 3) [27,17]. The latter chromitite type is much more massive and denser than the former one. The PGE content in the PGE-rich 
chromitite ranges from 800 up to $1500 \mathrm{ppb}$, while it is reached up to $320 \mathrm{ppb}$ in the PGE-poor mantle chromitite [27, unpublished data]. The Pd/Ir ratio of both chromitite types in the deeper mantle section is very low; it is much lower in the PGE-rich type, 0.007 , than in the PGE-poor one, 0.098 [27]. Most PGE mineralization is found in the PGE-rich chromitite samples, named 11, 67 and 68 (see Tables 2) of Wadi Hilti (Fig. 1B); although the PGE-poor mantle chromitites, 26, 39, 43 and 44 (see Table 2), also have some PGM inclusions.

Almost all the analyzed Os-rich PGM in both ophiolites are included within fresh chromian spinels, except in a few cases where PGM are associated with interstitial silicate matrix and chromian spinel cracks [17]. The majority of the analyzed PGM is Os-rich laurite $(\mathrm{Ru}, \mathrm{Os}, \mathrm{Ir}) \mathrm{S}_{2}$, while very few grains are erlichmanite $\left(\mathrm{OsS}_{2}\right)$ and Os-Ir alloys. In most cases Os-rich laurite is found as solitary grains of perfect euhedral crystals embedded within fresh chromian spinel (Fig. 4A and B). The Os-rich laurite of similar morphology and chemical composition has also been observed in the interstitial olivine matrix (Fig. 4C) and within cracks in chromian spinel. The grain size of the analyzed PGM occasionally exceeds $5 \mu \mathrm{m}$, and even up to $50 \mu \mathrm{m}$ across. Erlichmanite is also found as euhedral to subhedral crystals of up to $5 \mu \mathrm{m}$ across within fresh chromian spinel (Fig. 4D). Like the PGE sulfides, Os-Ir alloys are occasionally embedded within fresh chromian spinel showing subhedral to rounded shapes less than $5 \mu \mathrm{m}$ across $[17,27]$.

\section{Analytical methods}

The polished thin sections of the chromitite samples were carefully examined with the optical microscope and electron microprobe for identification and quantitative analysis at Kanazawa University, Japan, prior to Os-isotope analysis. Eighty PGM grains were analyzed for Os-isotope ratios. Fifty five grains are from the Oman ophiolite; 32 grains from PGE-rich 
mantle chromitite (31 Os-rich laurite grains and one grain of Os-Ir alloy), 16 grains from the PGE-poor mantle chromitite (all Os-rich laurite), and 7 grains from MTZ chromitite (6 Osrich laurite grains and one erlichmanite grain). Twenty five Os-rich laurite grains are from the Proterozoic ophiolite, Eastern Desert, Egypt; 24 grains from the CED chromitites and one big grain (> $50 \mu \mathrm{m}$ across) from a SED chromitite.

Osmium isotope ratios for Os-rich laurite, erlichmanite and PGE alloy inclusions in spinel were determined in situ using the Cameca $3 \mathrm{f}$ ion microprobe at Woods Hole Oceanographic Institution, Massachusetts, USA, using energy filtering techniques described by [28], with a 5 to $10 \mathrm{nA}$ primary beam of negatively charged oxygen and an energy window of 40-100 eV. Spot size varied from about 10 to 30 microns, and was sometimes larger than the PGM grains we wished to analyze. However, analyses of host spinel grains showed that they contained negligible quantities of Re and Os, so that the measured isotope ratios reflect the abundances of Re and Os isotopes in the PGM grains.

The counting cycle consisted of 2 seconds each on background, mass 185, mass 188 and mass 189 and 6 seconds on mass 187 . We initially measured ${ }^{186}$ Os as well, and followed the procedure of $[2,3]$ to correct for Os-hydride interference on ${ }^{187} \mathrm{Os},{ }^{188} \mathrm{Os}$ and ${ }^{189} \mathrm{Os}$. However, because ${ }^{186}$ Os count rates were low, obtaining accurate data was slow, and the resulting corrections for ${ }^{187} \mathrm{Os} /{ }^{188} \mathrm{Os}$ and ${ }^{189} \mathrm{Os} /{ }^{188}$ Os were small. The small size of the PGM grains in our samples dictated that we should collect essential data quickly, before grains were completely sputtered away, and so we excluded ${ }^{186}$ Os from our analytical routine. In principle, measured ${ }^{185} \mathrm{Re}$ could be used to estimate and correct for isobaric interference of ${ }^{187} \mathrm{Re}$ on ${ }^{187} \mathrm{Os}$. However, in practice, the ${ }^{185} \mathrm{Re} /{ }^{188}$ Os ratio averaged 0.00037 , and never exceeded 0.002 (Tables 1 and 2). The average value corresponds to ${ }^{187} \mathrm{Re} /{ }^{188} \mathrm{Os}$ of 0.0006 , which is within the uncertainty of the ${ }^{187} \mathrm{Os} /{ }^{188} \mathrm{Os}$ measurement in typical grains in our samples, so that no correction for Re interference is necessary. 
Sixteen analyses of a laurite "internal standard" (Amandelbult mine, Bushveld) yielded an average ${ }^{187} \mathrm{Os} /{ }^{188} \mathrm{Os}$ of 0.1766 with a standard deviation $(2 \sigma) \pm 2.6 \%$, and a standard error $(2 \sigma) \pm 0.64 \%$. In almost all cases each analysis represents one grain, but in some cases represents an average for several grains. Isotope ratios, including ${ }^{187} \mathrm{Os} /{ }^{188} \mathrm{Os}$, showed time-dependent variations at the end of some analyses when the sulfide or alloy grains in our samples were almost completely exhausted. We removed these time-dependent data and other outliers when calculating isotope ratios and their uncertainties for each spot, by excluding cycles where ${ }^{187} \mathrm{Os} /{ }^{188} \mathrm{Os}$ deviated more than $2.5 \sigma$ from the average of all cycles. To ensure there is no time-dependent in the data, number of cycles analyzed in each PGM is used to be plotted against the isotopic ratios to confirm that the ${ }^{187} \mathrm{Os} /{ }^{188} \mathrm{Os}$ ratio is not affected by the time of sputtering of the PGM grains (see Figs. 6 and 7).

After outliers were eliminated, ${ }^{189} \mathrm{Os} /{ }^{188} \mathrm{Os}$ in the Amandelbult "standard" averaged 1.2196 with a standard deviation $(2 \sigma) \pm 1.5 \%$, and a standard error $(2 \sigma) \pm 0.38 \%$. In our samples the average ${ }^{189} \mathrm{Os} /{ }^{188} \mathrm{Os}$ is 1.2061 with a standard deviation $(2 \sigma) \pm 2.7 \%$, and a standard error $(2 \sigma) \pm 0.34 \%$. The ${ }^{189} \mathrm{Os} /{ }^{188} \mathrm{Os}$ ratio of individual analysis was not used for fractionation correction because the variation in ${ }^{189} \mathrm{Os} /{ }^{188}$ Os between analyses did not appear to be related to mass fractionation in a systematic fashion (i.e., there is no negative correlation between ${ }^{189} \mathrm{Os} /{ }^{188} \mathrm{Os}$ and ${ }^{187} \mathrm{Os} /{ }^{188}$ Os for the 16 analyses of the Amanelbult standard).

A number of bulk rocks were also analyzed for Os concentration and isotopic composition (Table 3) using Ni-sulfide fire assay decomposition, followed by sparging into an ELEMENT ICP/MS at Woods Hole Oceanographic Institution. Complete details of these techniques, including information on blanks and reproducibility, can be found in $[29,30]$.

\section{Results}


The averages of Re-Os isotope compositions $\left({ }^{185} \mathrm{Re} /{ }^{188} \mathrm{Os} \pm\right.$ standard error, ${ }^{187} \mathrm{Os} /{ }^{188} \mathrm{Os}$ \pm standard error, and the initial Os isotope, $\gamma \mathrm{Os}_{(\mathrm{t})=0}$, calculated from the comparison with the present-day chondritic mantle [31], of all the analyzed PGM grains in the Eastern Desert and Oman ophiolites are listed in Tables 1 and 2, respectively. The ${ }^{187} \mathrm{Os} /{ }^{188} \mathrm{Os}$ ratios, $\gamma \mathrm{Os}_{(\mathrm{t})=0}$, and Os concentrations of some bulk rock samples are listed in Table 3. The Os-isotope ratios are generally less radiogenic for the bulk rock samples than for the in-situ PGM grains with the exception of CED of Egypt, and possibly the Oman MTZ, which plot symmetrically around the 1:1 line (Fig. 5). This may be attributed to the heterogeneous distribution of minute PGM grains in chromitite pods, i.e. nugget effect. It is noteworthy that almost all the analyzed PGM grains are chemically and optically homogeneous [27]. Due to the extremely low ${ }^{185} \mathrm{Re}$ content in almost all the analyzed PGM grains (Tables 1 and 2) there is no detectable contribution of radiogenic ${ }^{187} \mathrm{Os}$ in the measured Os ratios. Also, the presence of wellpreserved, isolated PGM grains within chromian spinel, and the lack of Os isotope differences between these grains and the few grains we analyzed which were not included in pristine spinel, precludes contribution of radiogenic ${ }^{187}$ Os from surrounding rocks and/or fluids. Consequently, the measured ${ }^{187} \mathrm{Os} /{ }^{188} \mathrm{Os}$ ratios are interpreted as the initial ratios at the time of formation of PGM.

The ${ }^{187} \mathrm{Os} /{ }^{188}$ Os ratios in the analyzed PGM in the CED chromitites of Egypt range from 0.11917 up to 0.12603 , with an average of 0.12261 , and $\gamma \mathrm{Os}_{(\mathrm{t})=0}$ ranges from $(-2.05)$ to $(-$ 7.33), with an average of (-4.63) (Table 1). Considering the time of formation (see Fig. 8), this average ratio is slightly lower (sub-chondritic) than the evolution trends of various present day mantle reservoirs (e.g. depleted mantle MORB materials (DMM), 0.1246 [32], primitive upper mantle (PUM), 0.1296 [33,34], chondritic mantle, 0.1270 [1] or 0.12863 [31], or convecting upper mantle, 0.12809 [10]). Only a single large PGM grain has been analyzed 
in the SED chromitite. Its ${ }^{187} \mathrm{Os} /{ }^{188}$ Os ratio 0.12928 is higher than any of the CED PGM grains (Table 1 and Fig. 6).

Despite the clear compositional difference in spinel composition and ${ }^{187} \mathrm{Os} /{ }^{188} \mathrm{Os}$ ratios of enclosed PGM between the CED and SED chromitites, the bulk composition of the Osisotope values (Table 3 and Fig. 5) do not show any significant differences between the two chromitite suites. This may be due to the limited number of bulk samples analyzed (only two samples) which will not show any real variations, if any.

The ${ }^{187} \mathrm{Os} /{ }^{188}$ Os ratios in the northern Oman chromitites show little variation between the different ore types. There is overlap in ${ }^{187} \mathrm{Os} /{ }^{188} \mathrm{Os}$ ratio for the three chromitite types (PGE-poor mantle chromitites, PGE-rich mantle chromitites, and MTZ chromitites) (Fig. 7 and Table 2). However, the PGE-poor mantle chromitite has a slightly higher average ${ }^{187} \mathrm{Os} /{ }^{188}$ Os compared to the PGE-rich mantle chromitite. The PGM grains of the PGE-rich mantle chromitite have a wide variation from sub-chondritic to supra-chondritic ${ }^{187} \mathrm{Os} /{ }^{188} \mathrm{Os}$ ratios. The minimum (sub-chondritic) ratio is 0.12303 with $\gamma \mathrm{Os}_{(\mathrm{t})=0}$ of $(-4.38)$, while the maximum (supra-chondritic) is 0.13765 with $\gamma \mathrm{Os}_{(\mathrm{t})=0}$ of $(+7.05)$ (Table 2). If we eliminate PGM grains of one sample (No. 11) displaying the highest ${ }^{187} \mathrm{Os} /{ }^{188} \mathrm{Os}$ values, the average of all analyzed PGM in the PGE-rich mantle chromitite is 0.12952 with $\gamma \mathrm{Os}_{(\mathrm{t})=0}$ of $(+0.69)$, being close to the PUM evolution trend $[33,34]$ or with the chondritic mantle value $[1,31]$.

The ${ }^{187} \mathrm{Os} /{ }^{188} \mathrm{Os}$ ratios of the PGM from PGE-poor mantle chromitite samples are supra-chondritic, ranging from 0.13087 up to 0.13742 , with an average of 0.13386 . The $\gamma \mathrm{Os}_{(\mathrm{t})=0}$ ranges from $(+1.77)$ up to $(+6.82)$, with an average of $(+4.07)$ (Table 2 and Fig. 7). These data lie within the range inferred for mid-ocean ridge basalt (MORB), $\sim 0.130-0.135$ $[35,36,32,4]$. The PGM in the MTZ chromitites, on the other hand, show a wide range of ${ }^{187} \mathrm{Os} /{ }^{188} \mathrm{Os}$ ratios, from 0.1208 to 0.1459 , with an average of 0.1322 , and $\gamma \mathrm{Os}_{(\mathrm{t})=0}$ ranges from 
$(-6.09)$ to $(+13.50)$ (Table 2 and Fig. 7), covering the entire range of values from the PGEpoor and PGE-rich mantle chromitites.

The Os-isotope compositions of bulk chromitites from the Oman ophiolite display the same variations like those of PGM grains in different chromitite types (Table 3 and Fig. 5). The PGE-rich and PGE-poor chromitites are relatively indistinguishable in their bulk Osisotope ratios, and their values are close to or slightly depleted relative to the bulk earth. Compared with the in-situ values for PGM grains, the bulk-rock values seem to only overlap the lower values of the range for the in-situ data of PGM grains (Fig. 5). This indicates that the PGM in the chromitite are heterogeneous in Os-isotope ratio and the observed PGM grains with high ${ }^{187} \mathrm{Os} /{ }^{188}$ Os values are less abundant than grains with lower values. The PGErich chromitite sample (No. 11), which shows the highest average ${ }^{187} \mathrm{Os} /{ }^{188}$ Os values in the PGM, also yields the highest bulk Os-isotope value (Table 3). The MTZ chromitite show more radiogenic bulk Os-isotope values (Table 3 and Fig. 5); for example, the sample (No. 60), which contains the PGM grains with the highest ${ }^{187} \mathrm{Os} /{ }^{188}$ Os ratio, also yields the highest bulk Os-isotope ratio $\left({ }^{187} \mathrm{Os} /{ }^{188} \mathrm{Os}=0.1375\right.$, and $\gamma \mathrm{Os}_{(\mathrm{t})=0}$ of $(+6.9)$, Table 3$)$ of all. The bulk Os-isotope compositions of Oman chromitites in this study are completely included within the range of ophiolitic chromitites [10], showing more or less a chondritic signature except the MTZ chromitites that display the supra-chondritic character.

\section{Discussion}

\subsection{Osmium-isotope studies on ophiolites: overview}

A shallow mantle source with Re/Os systematics analogous to the MORB composition is well presented by ophiolites, especially from the early precipitates such as PGM in 
chromitites [1]. Ophiolites, fragments of oceanic lithosphere ranging from basaltic lavas to residual mantle peridotites, are emplaced onto continental margins by obduction. Thus, many ophiolites are linked to supra-subduction zone processes [37]. Many ophiolites are interpreted to have been derived from spreading centers above subduction zones, e.g. back-arc basins [38], or from the lithosphere formed at a mid-ocean ridge and later experienced arc magmatism prior to obduction $[39,40,27]$. The careful determination of the in-situ Re-Os isotope systematics of encapsulated PGM in chromian spinel, combined with other petrological characteristics, could constrain the tectonic setting of ophiolite formation because the low Re/Os ratio of residual mantle samples may provide a relatively precise initial Os isotopic composition [7].

There have been few studies on the Os-isotope systematics of Phanerozoic ophiolites. Almost all of them focus on whole-rock isotopic compositions $[41,42]$. The studies on oceanfloor rocks demonstrate a range of Os isotopic compositions, from the least radiogenic ones observed in abyssal peridotites ranging from 0.120 to 0.129 , with an average of 0.1246 , to the more radiogenic ones in MORB ranging from 0.127 to $0.20[35,36,32,43]$. Melcher and his co-workers [44] studied the Re-Os isotopic systematics of a giant chromitite pod at Kempirsai, southern Urals. They concluded that the chromitite probably formed in a supra-subduction zone setting, but the contribution of radiogenic Os from a continental source is not detectable due to the high initial Os content of the already depleted mantle rocks [44]. Recently, Walker and his co-workers [10] reported Re-Os isotope systematics of chromian spinel separated from chromitites and dunites in the uppermost part of the mantle and overlying lower crustal section of 18 ophiolites. They concluded that ophiolitic chromites provide a coherent constraint on the Os isotope compositions of the shallow mantle during the past $1000 \mathrm{Ma}$. The Os isotope data of ophiolitic chromitites in their study reflect a "depleted MORB mantle" (DMM) signature, analogous to the present-day MORB source. 
In general, the Os isotope composition of whole-rock chromite concentrates does not consider the heterogeneous distribution of minute PGM grains within chromitite pods. This may lead to discrepancy in the Os-isotope ratios between whole rock and PGM analyses of the same pod. Disintegration of chromitite into different grain size fractions yields a fine fraction enriched in $\mathrm{Re}$ and $\mathrm{Pd}$, and having more radiogenic ${ }^{187} \mathrm{Os} /{ }^{188} \mathrm{Os}$, than coarser fractions which are less radiogenic and, because they contribute more mass to the whole rock, approach bulk rock ${ }^{187} \mathrm{Os} /{ }^{188} \mathrm{Os}[45]$. This will strongly affect the real distribution of PGE in the host rock and consequently the initial Os isotope values. Instead, the Os-rich PGM encapsulated within fresh chromian spinel are likely the best materials to constrain the initial ${ }^{187} \mathrm{Os} /{ }^{188} \mathrm{Os}$ values.

There have been very few studies on the Os-isotope compositions for older ophiolites. Bulk-rock Re-Os isotope systematics have been examined for two early Proterozoic ophiolites, the Outokumpu and Jormua $[7,46]$. The Os-isotope ratios are more or less chondritic, but are significantly heterogeneous in these early Proterozoic ophiolites [7]. The authors concluded that the least radiogenic Os is representative of the primary magmatic mantle source, whilst the more radiogenic materials reflect contamination either by sea water or by continental crust [7].

Younger ophiolites of late Proterozoic age, the Morro Feio and Cromínia ophiolites, Brazil, and the Al' Ays ophiolite, Saudi Arabia, were recently examined [10]. Radiogenic Os in the Al'Ays ophiolitic chromitite was attributed to addition of ${ }^{187}$ Os by metasomatic fluids related to subduction. Recently, Malitch and his co-workers [9] have examined the Re-Os isotope systematics of PGM in podiform chromitites at Kraubath and Hochgrössen, Austria, of Late Proterozoic age (780 - $550 \mathrm{Ma}, \mathrm{Sm}-\mathrm{Nd}$ age). They concluded that the Kraubath and Hochgrössen chromitites are characterized by unradiogenic ${ }^{187} \mathrm{Os} /{ }^{188}$ Os values, indicative to a sub-chondritic mantle source for PGE. More recently [47], two Neoproterozoic ophiolite-type 
ultramafic massifs (Kunar in Northern Taimyr, Russia, and Kraubath in Eastern Alps, Austria) were examined for their Os isotope compositions. The results reveal two different isotope sources, sub-chondritic and supra-chondritic, for bedrock Ru-Os sulfides at Kraubath, whereas unradiogenic ${ }^{187} \mathrm{Os} /{ }^{188} \mathrm{Os}$ values for the detrital Ru-Os-Ir alloys at Kunar which indicate a chondritic or sub-chondritic mantle source of PGE. The study also demonstrated that the Re-Os system in PGM remained unchanged from the time of formation of the PGM until now $[9,47]$.

\subsection{Interpretation of Os-isotope data}

\subsubsection{Late Proterozoic ophiolite, Egypt}

Being consistent with the spinel compositions (Fig. 2), there is a clear difference in Os isotope ratios between the CED and SED chromitites of Egypt. The earlier has a subchondritic average ${ }^{187} \mathrm{Os} /{ }^{188} \mathrm{Os}$ of 0.12261 and $\gamma \mathrm{Os}_{(\mathrm{t})=0}(-4.68)$, while the latter has a suprachondritic ${ }^{187} \mathrm{Os} /{ }^{188} \mathrm{Os}$ of 0.12928 and $\gamma \mathrm{Os}_{(\mathrm{t})=0}(+0.51)$ (Table 1). Osmium in the CED samples probably was derived from the mantle, while the SED sample has more radiogenic Os compositions than the value predicted for mantle-derived materials (Fig. 6). Due to the immobility of Os during serpentinization $[47,48]$ and to the fact that almost all the PGM grains we analyzed are completely enclosed in unaltered, fracture-free spinel crystals, the variation in ${ }^{187} \mathrm{Os} /{ }^{188} \mathrm{Os}$ ratios in the late Proterozoic ophiolitic chromitites of Egypt probably

reflects the heterogeneity of the upper mantle in Re/Os ratios. In addition, the very low ${ }^{185} \mathrm{Re}$ and ${ }^{185} \mathrm{Re} /{ }^{188}$ Os ratios of the studied PGM grains (Table 1) reflect their primary, magmatic origin in the mantle. 
The isotopic heterogeneity of mantle rocks was attributed to at least two factors; (1) addition or subtraction of $\mathrm{Re}$, and (2) addition of Os with different isotope ratios to the depleted mantle source [7]. The least radiogenic values are most probably characteristic of the primary magmatic mantle system [7], whereas the more radiogenic ones are attributed to the assimilation of crustal material or to the interaction with sea water $[49,50,29]$. The interaction with sea water; however seems not to be realistic. The radiogenic character of some mantle peridotites is not inherited or affected by sea water [48], since large volumes of sea water are required to shift the ${ }^{187} \mathrm{Os} /{ }^{188} \mathrm{Os}$ ratio towards radiogenic values. Instead, magmatic sulfides (the main carrier of Re) may cause the radiogenic affinity of some mantle sources [48]. The sub-chondritic ${ }^{187} \mathrm{Os} /{ }^{188}$ Os ratio in the CED samples (Fig. 8) suggests that the mantle source was the product of a previous melt depletion event, and thus had a lower Re/Os ratio than PUM of a comparable age [51].

The supra-chondritic ${ }^{187} \mathrm{Os} /{ }^{188}$ Os ratio (Fig. 8) of the SED sample, combined with the highly refractory nature of its chromitite spinel (Fig. 2), is probably due to recycling of radiogenic Os from subducted crust or due to second-stage melting in the mantle wedge. Although there is no firm evidence for radiogenic character of the mantle wedge, it is assumed to be the appropriate place for crustal contamination and mixing of mantle and crust components via subducted slab. With time, the mixing of crust and mantle components above subduction zones, could result in supra-chondritic ${ }^{187} \mathrm{Os} /{ }^{188} \mathrm{Os}$ ratios of resultant rocks $[52,5,53]$. The subduction-related origin of the late Proterozoic ophiolite in the southern part of the Eastern Desert, Egypt, can be deduced from the very refractory nature of chromian spinel in its chromitite-dunite-harzburgite complexes (unpublished data). If the PGM in the CED chromitites with sub-chondritic ${ }^{187} \mathrm{Os} /{ }^{188} \mathrm{Os}$ ratios represent the initial Os-isotope composition of the mantle in the late Proterozoic ophiolite of Egypt, the supra-chondritic 
${ }^{187} \mathrm{Os} /{ }^{188} \mathrm{Os}$ ratio of the SED might be explained by the mixing of recycled, subduction components and sub-chondritic depleted mantle [44].

The Os-isotope data, combined with the petrological characteristics, of the late Proterozoic ophiolite of the Eastern Desert of Egypt, suggest that the mantle rocks of this ophiolite are representative of a lithosphere produced or modified in a subduction setting and not of the late Proterozoic equivalent to the DMM $[7,24]$. The ${ }^{187} \mathrm{Os} /{ }^{188} \mathrm{Os}$ ratios of the early Proterozoic Outokumpu ophiolite [7], and the Neoproterozoic ophiolite-type ultramafic massifs of Kraubath, Eastern Alps, Austria [47], ranging from sub-chondritic to suprachondritic (Fig. 8), are similar to those in the late Proterozoic ophiolite of Egypt.

\subsubsection{Phanerozoic ophiolite, Oman}

The origin of the Oman ophiolite is still controversial. There are two main hypotheses for its tectonic setting of derivation: a mid-ocean ridge [54,55], and supra-subduction zone [56,21]. An additional possibility is that the ophiolite initially formed at a mid-ocean ridge, and then was reworked in a subduction setting [39,40,57]. Recently, additional lines of evidence for magmatism in a subduction zone setting were documented from the northern part of the Oman ophiolite. Boninitic lavas were found in the Alley volcanics [58], and high-PGE chromitite, produced by crystallization from a high-degree partial melt at a supra-subduction zone setting, was described in the northern Oman mantle section [27]. PGE-poor chromitites, in the mantle section and along the MTZ, were formed from a lower-degree partial melt in an earlier mid-ocean ridge setting [27]. So far, there are few Os-isotope data on the Oman ophiolite in general, in particular on its chromitite deposits, and there is no in-situ Os-isotope data on PGM from the Oman ophiolite. Bulk Os-isotope composition of few chromitite samples from the Oman ophiolite [10] display more or less chondritic initial ${ }^{187} \mathrm{Os} /{ }^{188}$ Os ratios. 
In spite of the distinctive geochemical differences between the three chromitite types of the Oman ophiolite (see Fig. 3); they are almost indistinguishable in terms of their in-situ PGM ${ }^{187} \mathrm{Os} /{ }^{188}$ Os ratios, straddling the chondritic value (Fig. 8). Although the individual PGM grains within individual samples have similar ${ }^{187} \mathrm{Os} /{ }^{188} \mathrm{Os}$ ratios, there is a significant sample-to-sample heterogeneity within individual chromitite pods, especially for the PGErich mantle chromitites and MTZ chromitites. Although there is a complete overlap in the ${ }^{187} \mathrm{Os} /{ }^{188}$ Os ratio between the two mantle chromitite types, the PGE-poor ones tend to be more radiogenic (supra-chondritic) than the PGE-rich ones (Figs. 7 and 8). The in-situ PGM ${ }^{187} \mathrm{Os} /{ }^{188}$ Os ratio in the MTZ chromitite, on the other hand, ranges from 0.1208 to 0.1459 , with an average of 0.1322 , covering the whole range of the ratio observed in mantle chromitites (Figs. 7 and 8).

MORB-derived glasses and sulfides show a wide range of ${ }^{187} \mathrm{Os} /{ }^{188} \mathrm{Os}$ ratios, from 0.127 to more than $0.20[36,4,50]$. The average ${ }^{187} \mathrm{Os} /{ }^{188}$ Os ratio of 0.13386 in the PGM of the PGE-poor mantle chromitite samples of the Oman ophiolite is similar to the average value for MORB $(\sim 0.130-0.135)$, and is slightly more radiogenic than PUM and chondrite (Fig. 8) $[35,36,32]$. Based on correlations between ${ }^{187} \mathrm{Os} /{ }^{188} \mathrm{Os}$ ratios and other isotopic systems in several MORB suites, the substantial Os isotopic heterogeneities in MORB are related to the mantle source and are not a result of sea water contamination $[4,48]$. It was also assumed that [59] the Os isotope compositions of ophiolitic chromitites might be affected by radiogenic fluids derived from a subducting slab resulting in an increase in the ${ }^{187} \mathrm{Os} /{ }^{188} \mathrm{Os}$ ratios.

The analyzed PGM from the PGE-rich mantle chromitites of the Oman ophiolite show a wide range of Os-isotope values, extending to less radiogenic values than those in the PGEpoor mantle chromitite and the observed Os isotope range for MORB. Nevertheless, on the basis of spinel Cr\# and PGE contents, we believe that the parental magma for the PGE-rich chromitites probably formed by second stage melting of previously depleted mantle rocks in a 
supra-subduction zone setting [27]. Recycling of radiogenic Os from subducted crust via migration of melt or fluid into the overlying mantle wedge can increase the radiogenic Os in the resultant mixed melt [5]. In the case of PGE-rich chromitite of the Oman ophiolite, the wide variations of ${ }^{187} \mathrm{Os} /{ }^{188} \mathrm{Os}$ ratios may reflect a heterogeneous mantle wedge produced in this way.

The MTZ chromitites of the Oman ophiolite occasionally have gabbroic or feldspathic veins and patches within the pods. Furthermore, the interstitial matrix of chromitite spinel is usually amphibole and clinopyroxene, with little or no olivine [60,27]. The geochemical and petrological characteristics of the MTZ chromitites in the Oman ophiolite led to the suggestion that they may have formed by assimilation of gabbroic blocks in olivine-spinel saturated melt $[61,27]$. The ${ }^{187} \mathrm{Os} /{ }^{188} \mathrm{Os}$ ratio is more variable in the MTZ chromitites than in the mantle PGE-poor and PGE-rich ones. The wide variability of Os isotopic compositions in the Oman MTZ samples probably indicates variable degrees of assimilation of hydrothermally altered crustal materials. The highest ${ }^{187} \mathrm{Os} /{ }^{188}$ Os ratio in the analyzed PGM grains of the MTZ samples is obtained from the sample (No. 60) which also has the highest bulk Osisotope value confirming the highly radiogenic nature of the MTZ chromitites compared to the mantle chromitites.

\section{Concluding remarks}

1. In-situ ion microprobe analysis of Os-rich PGM inclusions in chromian spinel was carried out for Os isotopic composition on chromitites from two different ophiolite suites: the Proterozoic ophiolite, Eastern Desert, Egypt, and the Phanerozoic ophiolite of Oman. 
2. $\mathrm{PGM}$ in the CED samples of Egypt show a narrow range in ${ }^{187} \mathrm{Os} /{ }^{188} \mathrm{Os}$ ratios, lower than the value inferred for the primitive, chondritic upper mantle. This may be attributed to earlier removal of Re from a part of the upper mantle via melt extraction. One SED sample, on the other hand, has a supra-chondritic ${ }^{187} \mathrm{Os} /{ }^{188} \mathrm{Os}$ ratio. This might be due to recycling of subducted, radiogenic Os, perhaps via fluid or melt migration into the mantle wedge above a subduction zone.

3. The Os-isotope data of the late Proterozoic ophiolite complex of the Eastern Desert of Egypt is completely consistent with the petrological characteristics which clearly demonstrated that the mantle rocks of this ophiolite are not representative of the late Proterozoic equivalent of DMM. The ophiolite might represent a fragment of oceanic lithosphere that was modified in a subduction zone environment.

4. The ${ }^{187} \mathrm{Os} /{ }^{188} \mathrm{Os}$ ratios of PGM from three types of chromitite from the Oman ophiolite show a variation from sub-chondritic to supra-chondritic values. Mantle chromitite samples show less variable Os isotopic compositions than MTZ chromitites. The PGEpoor mantle chromitite shows a relatively narrow range of Os composition; this spread completely overlaps ${ }^{187} \mathrm{Os} /{ }^{188}$ Os values observed in the PGE-rich mantle chromitite, but is restricted to the more radiogenic end of the observed range. The restricted range of ${ }^{187} \mathrm{Os} /{ }^{188} \mathrm{Os}$ ratios in the PGE-poor mantle chromitite is comparable to the most commonly observed MORB values.

5. Despite the chondritic character of the ${ }^{187} \mathrm{Os} /{ }^{188} \mathrm{Os}$ ratios in PGE-rich mantle chromitites, there are significant sample-to-sample variations within the pod. These variations may reflect heterogeneous Os isotope ratios due to the mixing of highly depleted mantle materials and radiogenic Os components in the upper mantle. The high Cr\# of spinel and high PGE concentration in the PGE-rich mantle chromitite in 
addition to the wide variation of ${ }^{187} \mathrm{Os} /{ }^{188} \mathrm{Os}$ ratios suggest that this may have occurred in a supra-subduction zone environment.

6. The range of $\mathrm{PGM}{ }^{187} \mathrm{Os} /{ }^{188} \mathrm{Os}$ ratios in the $\mathrm{MTZ}$ chromitite overlaps and extends beyond the observed range in mantle chromitites of the Oman ophiolite. The wide variability of Os isotopic compositions may reflect variable degrees of assimilation of hydrothermally altered crustal materials.

7. The evolution of mantle Os isotope ratios obtained from in situ PGM analysis is clearly shown in ophiolites of different ages. A secular increase in the variability of mantle Os isotope ratios may be indicated.

\section{Acknowledgments}

The authors would like to acknowledge N. Shimizu for his assistance in the ion probe analysis. Ahmed and Arai are indebted to K. Kadoshima and J. Uesugi for their assistance in the field. We are grateful S. Miyashita and S. Umino for their discussion. Kelemen and Hanghøj were supported in this project by US National Science Foundation grants OCE9819666 and OCE-0118572. The first author's stay in the US and use of the Woods Hole Ion Microprobe Facility was supported by funds from the Charles Francis Adams Chair, held by Kelemen at the Woods Hole Oceanographic Institution. Constructive comments by F. Melcher and two anonymous reviewers as well as editorial handling by $\mathrm{H}$. Elderfield of the MS are greatly appreciated.

\section{References}


[1] S.B. Shirey, R.J. Walker, The Re-Os isotope system in cosmochemistry and hightemperature geochemistry. Ann. Rev. Earth Planet. Sci. Lett. 26 (1998) 423-500.

[2] S.R. Hart, E.D. Kinloch, Osmium isotope systematics in Witwatersrand and Bushveld ore deposits. Econ. Geol. 84 (1989) 1651-1655.

[3] K.H. Hattori, L.J. Cabri, S.R. Hart, Osmium isotope ratios of PGM grains associated with the Freetown layered complex, Sierra Leone, and their origin. Contrib. Mineral. Petrol. 109 (1991) 10-18.

[4] P. Schiano, J.-L. Birck, C.-J. Allègre, Osmium-strontium-neodymium-lead isotopic covariations in mid-ocean ridge basalt glasses and the heterogeneity of the upper mantle. Earth Planet. Sci. Lett. 150 (1997) 363-379.

[5] A.D. Brandon, R.A. Creaser, S.B. Shirey, R.W. Carlson, Osmium recycling in subduction zones. Science 272 (1996) 861-864.

[6] K.H. Hattori, K.-P. Burgath, S.R. Hart, Os-isotope study of platinum-group minerals in chromitites in Alpine-type ultramafic intrusions and the associated placers in Borneo. Mineral. Mag. 56 (1992) 157-164.

[7] R.J. Walker, E. Hanski, J. Vuollo, J. Liipo, The Os isotopic composition of Proterozoic upper mantle: evidence for chondritic upper mantle from the Outokumpu ophiolite, Finland. Earth Planet. Sci. Lett. 141 (1996) 161-173.

[8] M. Ohnenstetter, Z. Johan, A. Cocherie, A.M. Fouillac, C. Guerrot, D. Ohnenstetter, M. Chaussidon, O. Rouer, E. Makovicky, M. Makovicky, J. Rose-Hansen, S. Karup-Moller, D. Vaughan, G. Turner, R.A.D. Pattrick, A.P. Gize, I. Lyon, I. McDonald, New exploration methods for platinum and rhodium deposits poor in base-metal sulphides NEXTRIM. Trans. Inst. Mineral. Metall. Sect. B Appl. Earth. Sci. 108 (1999) B119B150. 
[9] K.N. Malitch, S.A. Junk, O.A.R. Thalhammer, F. Melcher, V.V. Knauf, E. Pernicka, E.F. Stumpfl, Laurite and ruarsite from podiform chromitites at Kraubath and Hochgrössen, Austria: new insights from osmium isotopes. Can. Mineral. 41 (2003) 331-352.

[10] R.J. Walker, H.M. Prichard, A. Ishiwatari, M. Pimentel, The osmium isotopic composition of convecting upper mantle deduced from ophiolitic chromites. Geochim. Cosmochim. Acta 66 (2002) 329-345.

[11] R.M. Shackleton, Review of late Proterozoic sutures, ophiolitic mélanges and tectonics of eastern Egypt and north-east Sudan. Geol. Rund. 83 (1994) 537-546.

[12] A.R. Bakor, I.G. Gass, C.R. Neary, Jabal Al Wask, northwestern Saudi Arabia: an Eocambrian bac-arc ophiolite. Earth Planet. Sci. Lett. 30 (1976) 1-9.

[13] I.G. Gass, The evolution of the Pan African crystalline basement in NE Africa and Saudi Arabia. J. Geol. Soc. London 134 (1977) 129-138.

[14] R.M. Shackleton, A.C. Ries, R.H. Graham, W.R. Fitches, Late Precambrian ophiolite mélange in the Eastern Desert of Egypt. Nature 285 (1980) 472-474.

[15] J.E. Quick, Geology and origin of late Proterozoic Darb Zubaydah ophiolite, Kingdom of Saudi Arabia. Geol. Soc. Am. Bull. 102 (1990) 1007-1020.

[16] T. Augé, Platinum-group-mineral inclusions in chromitites from the Oman ophiolite. Bull. Minéral. 109 (1986) 301-304.

[17] A.H. Ahmed, S. Arai, Platinum-group minerals in podiform chromitites of the Oman ophiolite. Can. Mineral. 41 (2003) 597-616.

[18] M.A. Elhaddad, The first occurrence of platinum group minerals (PGM) in a chromitite deposit in the Eastern Desert, Egypt. Mineral. Deposita 31 (1996) 439-445.

[19] F. Zaccarini, G. Garuti, Platinum-Group Minerals and chromite composition in Mesozoic, Paleozoic and Precambrian podiform chromitites: Examples from the Mediterranean area, 
the Ural chain and the Egyptian Eastern Desert. In: Mineral Deposits at the beginning of the $21^{\text {st }}$ century, Balkema, Rotterdam/Brookfield (2001) 685-688.

[20] A.H. Ahmed, S. Arai, Platinum-group elements mineralogy of late Proterozoic podiform chromitites from the Eastern Desert of Egypt: A preliminary result. Final proc. $7^{\text {th }}$ Biennial SGA Meeting, Athens, Greece. In: Eliopoulos et al. (Eds.), Mineral exploration and sustainable development, Millpress, Rotterdam (2003) 555-558.

[21] S.J. Lippard, A.W. Shelton, I.G. Gass, The ophiolite of northern Oman. Geol. Soc. Mem. 11 (1986) 187pp.

[22] A.H. Ahmed, Diversity of platinum-group minerals in podiform chromitites of the late Proterozoic ophiolite, Eastern Desert, Egypt. Ore Geol. Rev. (in press).

[23] T.H. Dixon, The evolution of continental crust in the late Precambrian Egyptian Shield. Ph.D. Thesis, 1979, University of California, San Diego.

[24] A.H. Ahmed, S. Arai, A.K. Attia, Petrological characteristics of the Pan African podiform chromitites and associated peridotites of the Proterozoic ophiolite complexes, Egypt. Mineral. Deposita 36 (2001) 72-84.

[25] B.R. Hacker, J.L. Mosenfelder, E. Gnos, Rapid emplacement of the Oman ophiolite: thermal and geochronologic constraints. Tectonics 15 (1996) 1230-1247.

[26] A. Nicolas, H. Al Azri, Chromite-rich and chromite-poor ophiolites: the Oman case. In: Tj. Peters et al. (Eds.), Ophiolite Genesis and Evolution of the Oceanic Lithosphere, Oman (1991) 261-274.

[27] A.H. Ahmed, S. Arai, Unexpectedly high-PGE chromitite from the deeper mantle section of the northern Oman ophiolite and its tectonic implications. Contrib. Mineral. Petrol. 143 (2002) 263-278.

[28] N. Shimizu, S.R. Hart, Application of the ion microprobe to geochemistry and cosmochemistry. Ann. Rev. Earth Planet. Sci. Lett. 10 (1982) 483-526. 
[29] J.J. Standish, S.R. Hart, J. Blusztajn, H.J.B. Dick. Os isotopes in abyssal peridotite chromites. Geochem. Geophys. Geosyst. 3 (2002) GC000161, 24 pp.

[30] B. Peucker-Ehrenbrink, W. Bach, S.R. Hart, J.S. Blusztajn, T. Abbruzzese, Rheniumosmium isotope systematics and platinum group element concentrations in oceanic crust from DSDP/ODP Sites 504 and 417/418. Geochem. Geophys. Geosyst. 4 (2003) GC000414, 8911.

[31] J.H. Chen, D.A. Papanastassiou, G.J. Wasserburg, Re-Os systematics in chondrites and the fractionation of the platinum group elements in the early solar system. Geochim. Cosmochim. Acta 62 (1998) 3379-3392.

[32] J.E. Snow, L. Reisberg, Os isotopic systematics of the MORB mantle: results from altered abyssal peridotites. Earth Planet. Sci. Lett. 133 (1995) 411-421.

[33] T. Meisel, R.J. Walker, J.W. Morgan, The osmium isotopic composition of the Earth's primitive upper mantle. Nature 383 (1996) 517-520.

[34] T. Meisel, R.J. Walker, A.J. Irving, J.-P. Lorand, Osmium isotopic compositions of mantle xenoliths: a global perspective. Geochim. Cosmochim. Acta 65 (2001) 13111323.

[35] C.E. Martin, Osmium isotopic characteristics of mantle-derived rocks. Geochim. Cosmochim. Acta 55 (1991) 1421-1434.

[36] M. Roy-Barman, C.J. Allègre, ${ }^{187} \mathrm{Os} /{ }^{188}$ Os ratios of Mid-ocean ridge basalts and abyssal peridotites. Geochim. Cosmochim. Acta 58 (1994) 5043-5054.

[37] A. Miyashiro, Classification, characteristics and origin of ophiolites. J. Petrol. 83 (1975) $249-281$.

[38] J.A. Pearce, S.J. Lippard, S. Roberts, Characteristics and tectonic significance of a suprasubduction zone ophiolites. In: B.P. Kokelaar, M.F. Howells (Eds.), Marginal basin geology. Geol. Soc. Sp. Publ. 16 (1984) 77-94. 
[39] F. Boudier, G. Ceuleneer, A. Nicolas, Shear zones, thrust and related magmatism in the Oman ophiolite: initiation of thrusting on an oceanic ridge. Tectonoph. 151 (1988) 275296.

[40] F. Michard, F. Boudier, B. Goffé, Obduction versus subduction and collision in the Oman case and other Tethyan settings. In: Tj. Peters et al. (Eds.), Ophiolite Genesis and Evolution of the Oceanic Lithosphere (1991) 447-467.

[41] J.M. Luck, C.J. Allègre, Osmium isotopes in ophiolites. Earth Planet. Sci. Lett. 107 (1991) 406-415.

[42] J.E. Snow, G. Schmidt, E. Rampone, Os isotopes and highly siderophile elements (HSE) in the Ligurian ophiolites, Italy. Earth Planet. Sci. Lett. 175 (2000) 119-132.

[43] A.D. Brandon, R.J. Walker, J.W. Morgan, G.G. Goles, Re-Os isotopic evidence for early differentiation of the Martian mantle. Geochim. Cosmochim Acta 64 (2000) 4083-4095.

[44] F. Melcher, W. Grum, T.V. Thalhammer, O.A.R. Thalhammer, The giant chromite deposits at Kempirsai, Urals: constraints from trace elements (PGE, REE) and isotope data. Mineral. Deposita 34 (1999) 250-272.

[45] F. Melcher, T. Meisel, A metamorphosed early Cambrian crust-mantle transition in the eastern Alps, Austria. J. Petrol. 45 (2004) 1689-1723.

[46] A. Tsuru, R.J. Walker, A. Kontinen, P. Peltonen, E. Hanski, Re-Os isotopic systematics of the Jormua ophiolite complex, NW Finland. Chem. Geol. 164 (2000) 123-141.

[47] K. Malitch, Osmium isotope constraints on contrasting sources and prolonged melting in the Proterozoic upper mantle: evidence from ophiolitic $\mathrm{Ru}-\mathrm{Os}$ sulfides and $\mathrm{Ru}-\mathrm{Os}-\mathrm{Ir}$ alloys. Chem. Geol. 208 (2004) 157-173.

[48] O. Alard, A. Luguet, N.J. Pearson1, W.L. Griffin, J-P. Lorand, A. Gannoun, K.W. Burton, S.Y. O'Reilly, In situ Os isotopes in abyssal peridotites bridge the isotopic gap between MORBs and their source mantle. Nature 436 (2005) 1005-1008. 
[49] M. Sharma, D.A. Papanastassiou, G.J. Wasserburg, The concentration and isotopic composition of osmium in the oceans. Geochim. Cosmochim. Acta 61 (1997) 32873299.

[50] M. Roy-Barman, G.J. Wasserburg, D.A. Papanastassiou, M. Chaussidon, Osmium isotopic composition and Re-Os concentrations in sulfide globules from basaltic glasses. Earth Planet. Sci. Lett. 154 (1998) 331-347.

[51] K.H. Hattori, S.R. Hart, Osmium-isotope ratios of platinum-group minerals associated with ultramafic intrusions: Os-isotopic evolution of the oceanic mantle. Earth Planet. Sci. Lett. 107 (1991) 499-514.

[52] R.J. Walker, L.M. Echeverria, S.B. Shirey, M.F. Horan, Os isotopic constraints on the origin of volcanic rocks, Gorgona Island, Colombia: Os isotopic evidence for ancient mantle heterogeneities. Contrib. Mineral. Petrol. 107 (1991) 150-162.

[53] R.J. Walker, E. Nisbet, ${ }^{187}$ Os isotopic constraints on Archean mantle dynamics. Geochim. Cosmochim. Acta 66 (2002) 3317-3325.

[54] A. Nicolas, Structures of ophiolites and dynamics of oceanic lithosphere. Dordrecht, Kluwer Academic Publishers (1989).

[55] B. Ildefonse, A. Nicolas, F. Boudier, Evidence from the Oman ophiolite for sudden stress changes during melt injection at oceanic spreading centers. Nature 366 (1993) 673-675.

[56] T. Alabaster, J.A. Pearce, J. Malpas, The volcanic stratigraphy and petrogenesis of the Oman ophiolite complex. Contrib. Mineral. Petrol. 81 (1982) 168-183.

[57] P.B. Kelemen, G. Hirth, N. Shimizu, M. Spiegelman, H.J.B. Dick, A review of melt migration processes in the asthenospheric mantle beneath oceanic spreading centers. Phil. Trans. Royal Soc. London A355 (1997) 283-318. 
[58] T. Ishikawa, K. Nagaishi, S. Umino, Boninitic volcanism in the Oman ophiolite: implications for thermal condition during transition from spreading ridge to arc. Geology 30 (2002) 899-902.

[59] A. Büchl, G. Brügmann, V. G. Batanova, Formation of podiform chromitite deposits: implications from PGE abundances and Os isotopic compositions of chromites from the Troodos complex, Cyprus. Chem. Geol. 208 (2004) 217-232.

[60] T. Augé, Chromite deposits in the northern Oman ophiolite: mineralogical constraints. Mineral. Deposita 22 (1987) 1-10.

[61] J.H. Bédard, R. Hébert, Formation of chromitites by assimilation of crustal pyroxenites and gabbros into peridotitic intrusions, North Arm Mountain Massif, Bay of Island ophiolite, Newfoundland, Canada. J. Geoph. Res. 103 (1998) 5165-5184. 